\title{
Antibacterial Activity of Ethyl Acetate Extract and Cream Formulation of Coleus atropurpureus Leaves against Staphyloccous aureus
}

\author{
Indra Lasmana Tarigan ${ }^{*}$, Afidatul Muadifah ${ }^{2}$, Nindita Clourisa Amaris Susanto ${ }^{3}$, Choirul Huda \\ 1,3 Kimia, MIPA, Fakultas Sains dan Teknologi, Universitas Jambi \\ 2,4.Farmasi, STIKes Karya Putra Bangsa, Tulungagung
}

\section{ARTICLE INFO}

Article

submission: 7

September 2021

Revision

submission: 25

Oktober 2021

Acceptance for

publication: 25

Oktober 2021

Keywords:

Coleus leaves, antibacterial activity, cream formulation

\section{ABSTRACT}

Introduction: The major cause of numerous infections in both communities and healthcare facilities is Staphylococcus aureus (Sa). Sa can attack and survive in epithelial cells including endothelial cells and is increasingly showing resistance to multiple antimicrobial agents. Attempts to overcome the infection caused by Sa by giving antibiotics, which work as antibacterial. Myana (Coleus atropurpureus L. Benth) leaves contain several active compounds that might act as antibacterial agents.

Objectives: This study aimed to analyze the antibacterial activity of Coleus extract and evaluate the formulation of the extract cream against the bacteria causing infection, Sa.

Methods: Coleus leaves ethyl acetate extract contains alkaloids and tannins. Our cream formulation with criteria: the $\mathrm{pH}$ value, homogeneity, spreadability, adhesion, and protection power. Our cream formulation results were then evaluated based on the standard, with criteria: the $\mathrm{pH}$ value, homogeneity, spreadability, adhesion, and protection power.

Results: The absorbance of Sa at the $3^{\text {rd }}$ hour was getting smaller, from 0.668 to 0.552 , this showed that the longer the incubation time of the extract against bacterial inoculation, the more bacteria died. It seems that our cream is per the cream standards. It is semi-solid, brownish-white in color, smells typical of Coleus, and $\mathrm{pH}$. Moreover, the cream is homogeneous with $5 \mathrm{~cm}$ of spreadability, 7 seconds for adhesion, and colorless.

Conclusions: Coleus extract cream has better antibacterial activity than positive control with a wound closure time of 7-14 days for extract while more than 14 days for positive control.

Keyword: Coleus leaves, antibacterial activity, cream formulation. 


\section{Introduction}

Infection is the process of entering and multiplying microorganisms such as bacteria, viruses, fungi, and parasites that cause tissue injury (1). Pathogenic bacteria produce toxic substances in the form of endotoxins and exotoxins, which cause mild to acute infection. Bacterial infections can occur in children and attack various organ systems, respiratory tract infections (27\%) (1), skin infections (7-10\%) (2), digestive tract infections (5\%) and urinary tract infections (0.7-0.9\%) (1). Infected body tissues react to infection with an innate response, often involving inflammation, followed by an adaptive response (3). Before bacteria multiply and cause symptoms, the immune system can usually kill the pathogenic bacteria. White blood cells attack harmful bacteria and even if symptoms appear, the immune system can usually overcome and fight off the infection. However, if the number of harmful bacteria is excessive, and the immune system cannot fight, then antibiotics are needed (4).

Antibiotics is antibacterial agents and antibacterial agents are agents used to fight bacterial infection (5). Antibiotics can kill or inhibit the growth of bacteria, interfere with the formation of cell walls by blocking the work of enzymes, causing damage to the cell walls (1), and interfering with the metabolic processes and protein synthesis in bacteria $(6,7)$. When an infection is suspected to be the cause of a disease but the type of bacteria has not been identified, empiric therapy is needed to be able to continue the use of broad spectrum antibiotics. Identification is very important because it can reduce the cost and toxicity of antibiotic therapy and also reduce the possibility of the emergence of antimicrobial resistance (3). The emergence of bacterial resistance to antibiotics is a common phenomenon. The emergence of resistance often reflects an evolutionary process that occurs during antibiotic therapy. MRSA is a type of Staphylococcus aureus that is pathogenic and causes many infections that have developed resistance to various antibiotics (8). The high prevalence of bacterial infections and resistance to antibacterials requires efforts to find new drug compounds candidates that can act as antibacterial candidates. Overuse or misuse of antibiotics cause resistance, and reported that some antibiotics are susceptible to bacterial resistance include acid glycosides (gentamicin, kanamycin, netilmicin, and tobramycin), cephalosporins (cephalexin, ceftizoxime, and ceftriaxone), penicillins (amoxicillin, sulbenicillin, penicillin $\mathrm{G}$, and ampicillin) as well as other groups such as tetracycline, ciprofloxacin (9), salicylates (SAL), chlorhexidine (CHX), isothiazolinone (ITZ), thiosemicarbazone (TSC), octenidine (OCT), and quaternary ammonium (QA) (10).

Natural antibacterials from natural ingredients can be used to meet the need for new sources of antibiotics, which have medicinal properties that play an important role in biological activity, as an indicator of the ability of these natural materials as a source of new medicinal compounds. Scientists approach both ethnobotany and chemotaxonomy (phytopharmaceuticals) to find chemical compounds from natural ingredients for medicinal sources (11). One of the plants that have the potential to be explored as a source of new antibacterial compounds is miana. Miana leaves (Coleus sp) contain flavonoids, steroids, tannins, and saponins which have anti-inflammatory, anti-allergic, antioxidant, and antibacterial effects (12). Miana leaf extract can inhibit Escherichia coli bacteria at a concentration of $15.62 \mathrm{mg} / \mathrm{ml}$ with a bacterial inhibition zone of $7 \mathrm{~mm}$ (12). One of the characteristics of miana plants is known to have many species based on their morphology (a) Aurora (b) Religious Radish (c) Red Trailing Queen (d) Trailing Bleeding Heart (e) Trailing Salamander (f) Ruby Ruffles (g) Vulcan (13). From a chemotaxonomic perspective, the study of bioactive compounds from various miana species is very interesting and important to do, to see the chemical diversity and potential for its development in drug formulations to make it easier to use and more efficient (14).

One of the many formulations developed is cream preparations as wound healing and anti-infection agents, with the advantages of being easy to dry (15), forming a film that is easy to wash, and providing a cooling feeling on the skin (16). The use of cream as an antibacterial material has been widely developed, and optimized so that the matrix remaining after the drug is released can be removed (17). Previous research reported that hydrogel has a fairly good ability to absorb water, it can be used to deliver drugs into the body (15)(18).

\section{Methods}

\section{Materials and Tools}

The test material used was Coleus atropurpureus L. Benth leaves with green color specifications we obtain from Batu City, East Java, which had previously been determined at Materia Medika Malang. The chemicals used in this study were miana leaves (Coleus sp), Ethanol, and Nutrient Agar (NA), n-hexane, chloroform, ethyl acetate, $5 \% \mathrm{FeCl}$, magnesium powder, concentrated $\mathrm{HCl}$, Dregendorff reagent, Wagner, Mayer, Anhydrous $\mathrm{CH} 3 \mathrm{COOH}$, concentrated $\mathrm{H} 2 \mathrm{SO} 4$, chloramphenicol, a combination of charbopol 940, gelatin, Na-CMC, Propylene glycol, Tetracycline antibiotic glycerol, and TEA (Sigma Aldrich). The equipment used in this study were maceration extraction equipment, Erlenmeyer, filter paper, separating funnel, evaporator, petri dish, L rod, oven, caliper, and hand mixer, Eppendorf $200 \mu \mathrm{L}$, analytical balance (And GR-300), rotary evaporator (Ryela N-1000), ultrasonic cleaner (WT-600- 40), water bath (Eyela SB1000), and glassware (Pyrex). The experimental animals used were male mice of the Balb-c strain obtained from the medical faculty of Brawijaya University, Malang.

\section{Sample preparation and Extraction.}

Coleus leaves that have been collected from Batu Regency, Malang, Indonesia are cleaned, washed, drained, and dried at room temperature (RT). The dried leaves were cut into small pieces, then ground to obtain miana powder (simplicia) (19). Extraction was carried out using the 
maceration method using ethyl acetate as a solvent. 500 grams of simplicia leaves macerated with ethyl acetate solvent for five days at RT then filtered to get the filtrate, collected in a maceration bottle. The dregs were stored in another container and macerated again with ethyl acetate three times. The entire filtrate obtained was concentrated with a rotary evaporator at a temperature of $50^{\circ} \mathrm{C}$ to obtained a thick extract (20).

\section{Phytochemical Screening.}

Phytochemical tests were carried out to determine the content of secondary metabolites in ethanolic extracts of Coleus leaves such as tannins, flavonoids, alkaloids, polyphenols, and steroids using phytochemical screening reagents (21) according to previous studies, which included: tannin and polyphenol screening using $\mathrm{FeCl} 3$ solution, flavonoid screening using Shinoda reagent), alkaloid test using Dragendorff reagent, while steroid test using anhydrous $\mathrm{CH} 3 \mathrm{COOH}$ and $\mathrm{H} 2 \mathrm{SO} 4$. A positive test is indicated by the formation of a specific color from each compound (19).

\section{The Antibacterial Activity of Leaves Extract.}

The antibacterial activity of the extract using the turbidity method. $25 \mathrm{ml}$ of Nutrient Agar (NA) media was mixed with $25 \mathrm{~L}$ of the appropriate test bacterial suspension. The antibacterial activity of extracts was tested to determine the ability of a bioactive compound to inhibit bacterial growth. Two types of bacteria were used Bacillus subtilis (Bs), Escherichia coli (Ec) dan Staphylococcus aureus (Sa) which were cultured in NB media then calculated $\mathrm{OD}(600 \mathrm{~nm})$ then perform in UV-Vis Spectrophotometry. The positive control used chloramphenicol, while the negative control used DMSO. We used different extract concentrations $10 \%, 15 \%$, and $25 \%$ (17).

\section{Cream Formulation}

The cream formulation uses the active substance of Coleus Leaves ethyl acetate extract with type M/A (vanishing cream). The cream was made in three formulas from the minimum inhibitory concentration of extract against Staphylococcus aureus (15\%) (19). The method of making M/A type cream (Vanishing Cream) is that the oil phase (white wax, stearic acid, and white vaseline) is melted over a water bath at a temperature of 750C. The aqueous phase (TEA and propylene glycol) was melted at a temperature of $750 \mathrm{C}$. The aqueous phase (a mixture of TEA and Propylene glycol) is then added to melted white wax, stearic acid, and white vaseline, then stirred until homogeneous in a warm mortar until a creamy mass is formed and methylparaben added. After the cream is cold, the leaves ethyl acetate extract was added to the cream (22).
Table 1. Cream formulations

\begin{tabular}{|c|c|c|c|c|c|}
\hline \multirow[b]{2}{*}{ Compounds } & \multicolumn{5}{|c|}{ Formulation (\%) } \\
\hline & $\mathrm{C}(+)$ & C (-) & F1 & F2 & F3 \\
\hline Tetracycline & 1 & - & - & - & - \\
\hline Extract & - & - & 0.25 & 0.5 & 1 \\
\hline White Nights & 2 & 2 & 2 & 2 & 2 \\
\hline Stearic acid & 15 & 15 & 15 & 15 & 15 \\
\hline White Vaseline & 8 & 8 & 8 & 8 & 8 \\
\hline Methyl paraben & 0.12 & 0.12 & 0.12 & 0.12 & 0.12 \\
\hline Aquadest & 100 & 100 & 100 & 100 & 100 \\
\hline
\end{tabular}

\section{Cream Characteristic.}

Extract characterization includes specific characterization which consists of examining the chromatographic pattern of the extract based on the polarity of the solvent through thin layer chromatography (TLC) and densitometry for Finger Print, testing of hydrogel characteristics including physical observations, $\mathrm{pH}$ measurements, viscosity measurements, and dispersion measurements (23). Organoleptic Test: The organoleptic test was carried out visually and directly to see the shape, color, and smell of the cream preparation. The cream is usually clear with a semi-solid consistency. Homogeneity Test: Take a sufficient amount of cream preparation, smear it on a glass object and then touch and rub it. The arrangement of the preparations on the glass object was observed. A homogeneous cream mass is indicated by the absence of solid or granular materials on the glass (24). Adhesion Test: A 0.25 -gram sample of cream is placed between 2 cream objects on the adhesion test equipment, pressed with a load of $1 \mathrm{~kg}$ for 5 minutes, then the load is lifted and the 80-gram load is released on the test equipment and the time of cream release is recorded (24). The requirement for good adhesion for topical preparations is more than 4 seconds (25). Spreadability Test: The cream preparation was weighed as much as $500 \mathrm{mg}$, placed in the middle of scaled round glass, and placed another round glass that had been weighed on top of the cream for 1 minute. The diameter of the spread cream was measured, then $50 \mathrm{~g}$ was added and allowed to stand for 1 minute.

The diameter of the cream spread and after the addition of a load of $100 \mathrm{~g}, 150 \mathrm{~g}$, and $200 \mathrm{~g}$ were recorded. The dispersion requirement for good topical preparation is $5-7 \mathrm{~cm}(25) . \mathrm{pH}$ test: The cream preparation was weighed as much as 1 gram and dissolved in $100 \mathrm{ml}$ of aqua distillate in a beaker cream. The $\mathrm{pH}$ of the solution was measured using a universal $\mathrm{pH}$ indicator for three replications and the average $\mathrm{pH}$ value was calculated. The $\mathrm{pH}$ requirement for good topical preparation is following the skin's natural $\mathrm{pH}$, which is 4.5-6.5 (25). Protection Test: The cream preparation is smeared on filter paper which has previously been dripped with phenolphthalein. The paper was affixed to another filter paper and then dropped with $0.1 \mathrm{~N} \mathrm{KOH}$ solution. The appearance of red color was observed at 15, 30, 45, 60 seconds, and 3 and 5 minutes (24). 


\section{In-vivo Antibacterial Activity of Leaf Extract.}

We were carried out on 25 rats randomized into five treatments with each treatment consisting of 5 replications. The in vivo model infection was colonization incisional by abrasion with a dose infective $(3 \times 108$ colony forming units $(\mathrm{CFU}) / \mathrm{mL}$ ) growing from 4 first hours in a selflimiting pattern. Two superficial abrasions were made in 25 mice under general anesthesia. Skin was disinfected with $70 \%$ alcohol and abrasions were carried out with a scalpel ( ${ }^{\circ}$ 11) until redness appeared and epidermis apparently was lost. Wounds were $\sim 0.6 \mathrm{~cm}$ in diameter and were located in the dorsal area and at a distance of $1 \mathrm{~cm}$. Wounds were infected with the inoculum previously obtained and protected with a transparent sticking plaster for $24 \mathrm{~h}$ (26). The test begins with giving each rat a bacterial infection wound and then the test is carried out according to the treatment group. Group $\mathrm{I}$ is a concentration of $1 \%$, Group II is a concentration of $0.5 \%$, Group III is a concentration of $0.25 \%$, Group IV is a negative control, and Group V is a positive control.

\section{Result and Discussion}

\section{The Phytochemical Screening}

Coleus leaves powder was prepared by 60 mesh with a weight of $400 \mathrm{~g}$ was macerated using $96 \%$ ethyl acetate solvent and concentrated. $1 \mathrm{~g}$ of the total extract was obtained then skinning fitokimia to obtain secondary metabolites. The screening results showed that the ethyl acetate extract of Coleus leaves contained alkaloids and tannin (Tabel 2).

Table 2. The phytochemical screening extract compounds

\begin{tabular}{ll}
\hline Secondary Metabolite & Result \\
\hline Alkaloids & + \\
\hline Flavonoids & - \\
\hline Tannins & + \\
\hline Saponins & - \\
\hline Steroids & - \\
\hline
\end{tabular}

The results of our previous antibacterial activity study showed that $15 \%$ Coleus leaves ethyl acetate extract had inhibition zones of $12.80 \mathrm{~mm}, 25 \%(17.00 \mathrm{~mm})$, and $35 \%$ $(39.60 \mathrm{~mm})$ (19). The cream formulation uses the active substance of coleus extract with type M/A (vanishing cream). The cream was made with three formulas of the minimum inhibitory concentration of myana leaf ethyl acetate extract against Staphylococcus aureus (15\%) (Table 1).
Figure 1. General Structure of Alkaloids (A), Tannins (B)<smiles>CN[C@@H](C)[C@H](O)c1ccccc1</smiles>

(A)<smiles>O=C(O)c1cc(O)c(O)c(O)c1</smiles>

(B)

\section{Antibacterial Activity}

The antibacterial activity of Coleus extract was carried out using the turbidimetric method by analyzing Optical Density (OD) 600nm against Bacillus subtilis (Bs), Escherichia coli (Ec), and Staphylococcus aureus (Sa) bacteria. From the graph (Figure 1) it shows that the larger the absorbance in Ec, the smaller the $\mathrm{Bs}$ and $\mathrm{Sa}$. Unfortunately, Ec is belongs to gram-negative bacteria with different cell walls, while $\mathrm{Bs}$ and $\mathrm{Sa}$ are grampositive. Gram positive bacteria possess a thick (20-80 $\mathrm{nm})$ cell wall as outer shell of the cell. In contrast Gram negative bacteria have a relatively thin $(<10 \mathrm{~nm})$ layer of cell wall, but harbour an additional outer membrane with several pores and appendices.

These differences in the cell envelope confer different properties to the cell, in particular responses to external stresses, including antibiotics (27). The antibacterial activity of a bioactive compound can be different due to the different mechanisms of inhibition. Furthermore, the antibacterials are classified into effective antibacterials that only inhibit gram-negative bacteria, effective antibacterials that only inhibit gram-positive bacteria, and antibacterials that effectively inhibit both (28). However, the absorbance of $\mathrm{Sa}$ at the 3rd hour was getting smaller, from 0.668 to 0.552 , this showed that the longer the incubation time of the extract against bacterial inoculation, the more bacteria died. This result is also of special interest to us, $\mathrm{Sa}$ is a bacterial pathogen that causes a lot of infection, so we continued the in vivo test using mice infected with Sa.

Figure 2. Antibacterial absorbance diagram

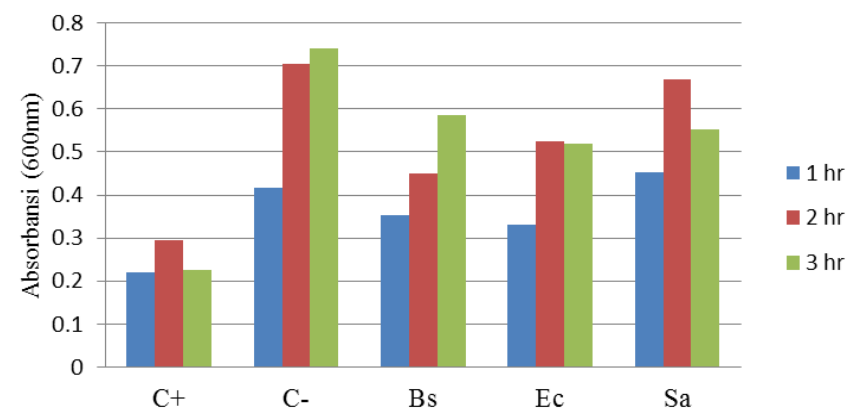

\section{Cream Formulation}

The formulation of the cream was carried out using a dose of $0.25 ; 0.5$, and $1 \%$ Coleus ethyl acetate extract (Table 3). The results of the cream obtained were then carried out with an evaluation test which included 
organoleptic examination, $\mathrm{pH}$ test, homogeneity test, spreadability, adhesion test, and protective power test (L.4.2) with the results as shown in Table 3.

Table 3. The cream formula evaluation

\begin{tabular}{|c|c|c|}
\hline Cream evaluation & Results & Standard \\
\hline \multicolumn{3}{|l|}{ Organoleptic } \\
\hline a. Shapes & Semi Solid & Semi Solid \\
\hline b. Colour & $\begin{array}{l}\text { Brownish } \\
\text { white }\end{array}$ & Transparent \\
\hline c. $\quad$ Smell & Typical & - \\
\hline d. $p H$ & 6 & $4.5-6.5$ \\
\hline Homogenity & Homogeneous & Homogeneous \\
\hline Spreadability & $5 \mathrm{~cm}$ & $5-7 \mathrm{~cm}$ \\
\hline Adhesion & 7 secon & $>4$ secon \\
\hline Protection power & Colorless & Colorless \\
\hline
\end{tabular}

Our cream formulation results were then evaluated based on the standard, with criteria: the $\mathrm{pH}$ value, homogeneity, spreadability, adhesion, and protection power. It seems that our cream is per the cream standards. It is semi-solid, brownish-white in color, smells typical of Coleus, and pH 6. Moreover, the cream is homogeneous with $5 \mathrm{~cm}$ of spreadability, 7 secon for adhesion, and colorless $(15,29)$.

\section{In vivo Antibacterial Activity of Cream Coleus Leaves Extract}

The formulated Coleus extract was analyzed macroscopically using Nagaoka parameters (Table 4). Our macroscopic observations were carried out by visually observing the closing process and giving an assessment score according to Nagaoka (30). Visual observations were made by observing wound closure and wound dryness that occurred with the sense of sight carried out on test animals every day, so that the wound closure process that occurred on days 3, 5, 7, 14, 21 Giving an assessment score for the healing of open wounds on the rabbit's back in (Table 5).

Table 4. Macroscopic wound assessment score

\begin{tabular}{|c|c|c|c|c|c|c|c|c|c|c|}
\hline \multirow{3}{*}{ Group } & \multicolumn{9}{|c|}{ Nagaoka Parameters } & \\
\hline & \multicolumn{3}{|c|}{$\begin{array}{l}\text { Wound } \\
\text { Closing } \\
\text { Time (a) }\end{array}$} & \multicolumn{3}{|c|}{$\begin{array}{c}\text { Local } \\
\text { Infection (b) }\end{array}$} & \multicolumn{3}{|c|}{$\begin{array}{l}\text { Allergy } \\
\text { (c) }\end{array}$} & \multirow{4}{*}{ Score } \\
\hline & $<7$ & $7-14$ & $>1$ & $\mathrm{~N}$ & WP & $\mathrm{P}$ & $\mathrm{N}$ & $\mathrm{A}$ & $\mathrm{R}$ & \\
\hline & d & $\mathrm{d}$ & $4 \mathrm{~d}$ & I & & & A & & $\mathrm{S}$ & \\
\hline & 3 & 2 & 1 & & 2 & & & 3 & 1 & \\
\hline
\end{tabular}

Sample

$a+b+c$

(NI: Not Infection ; WP: Without Pus; P : Pus ; NA : Not allergy; A : Allergy; BM: Red Spot)

The results of our phytochemical screening showed that the Coleus ethyl acetate extract contained alkaloids and tannins, with the tannin concentration being more dominant. Alkaloids and tannins are metabolites that have bioactivity as antibacterial, antimicrobial, antioxidant, and antidiabetic (31). The results of our previous antibacterial test showed that $15 \%$ of the Coleus ethyl acetate extract had an inhibition zone diameter of $12 \mathrm{~mm}$ agains Sa (19).

Furthermore, we tested the antibacterial activity of the extract against three bacteria $\mathrm{Bs}$, Ec, and $\mathrm{Sa}$ using the turbidimetric method, and showed interesting results for $\mathrm{Sa}$, that the absorbance of $\mathrm{Sa}$ at the 3rd hour was getting smaller, from 0.668 to 0.552 .

Table 5. Criteria Macroscopic Assessment Score

\begin{tabular}{|c|c|c|c|c|c|}
\hline \multirow[b]{2}{*}{ Groups } & \multicolumn{3}{|c|}{ Parameters } & \multicolumn{2}{|c|}{ Score } \\
\hline & $\begin{array}{l}\text { Wound } \\
\text { healing }\end{array}$ & $\begin{array}{c}\text { Local } \\
\text { Infectio } \\
\text { n }\end{array}$ & Allergic & Total & $\begin{array}{c}\text { Aver } \\
\text { age }\end{array}$ \\
\hline
\end{tabular}

\begin{tabular}{|c|c|c|c|c|c|}
\hline Cream1 & & & & & \\
\hline Mice 1 & 2 & 3 & 3 & 8 & \multirow{5}{*}{8} \\
\hline Mice 2 & 2 & 3 & 3 & 8 & \\
\hline Mice 3 & 2 & 3 & 3 & 8 & \\
\hline Mice 4 & 2 & 3 & 3 & 8 & \\
\hline Mice 5 & 2 & 3 & 3 & 8 & \\
\hline \multicolumn{6}{|c|}{ Cream $0.5 \%$} \\
\hline Mice 1 & 2 & 3 & 3 & 8 & \multirow{5}{*}{7.8} \\
\hline Mice 2 & 1 & 3 & 3 & 7 & \\
\hline Mice 3 & 2 & 3 & 3 & 8 & \\
\hline Mice 4 & 2 & 3 & 3 & 8 & \\
\hline Mice 5 & 2 & 3 & 3 & 8 & \\
\hline \multicolumn{6}{|c|}{ Cream $0.25 \%$} \\
\hline Mice 1 & 2 & 3 & 3 & 8 & \multirow{5}{*}{7.8} \\
\hline Mice 2 & 2 & 3 & 3 & 8 & \\
\hline Mice 3 & 2 & 3 & 3 & 8 & \\
\hline Mice 4 & 1 & 3 & 3 & 7 & \\
\hline Mice 5 & 2 & 3 & 3 & 8 & \\
\hline \multicolumn{6}{|c|}{ Control + } \\
\hline Mice 1 & 2 & 3 & 3 & 8 & \multirow{5}{*}{8} \\
\hline Mice 2 & 2 & 3 & 3 & 8 & \\
\hline Mice 3 & 2 & 3 & 3 & 8 & \\
\hline Mice 4 & 2 & 3 & 3 & 8 & \\
\hline Mice 5 & 2 & 3 & 3 & 8 & \\
\hline \multicolumn{6}{|c|}{ Control - } \\
\hline Mice 1 & 1 & 2 & 3 & 6 & \multirow{5}{*}{6} \\
\hline Mice 2 & 1 & 2 & 3 & 6 & \\
\hline Mice 3 & 1 & 2 & 3 & 6 & \\
\hline Mice 4 & 1 & 2 & 3 & 6 & \\
\hline Mice 5 & 1 & 2 & 3 & 6 & \\
\hline
\end{tabular}

The ethyl acetate extract was then formulated into cream to be tested in vivo on mice infected with Sa. The resulting formulations were characterized by their physical properties, and all formulas were within the standard characteristics. The infected mice were then treated using five formulations $(\mathrm{C}-; \mathrm{C}+; \mathrm{F} 1 ; \mathrm{F} 2 ; \mathrm{F} 3)$ and the ability to close the wound was observed.

Figure 3. The activity of Coleus leaves cream against Mice Infected with S. aureus

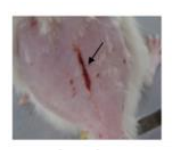

Control -

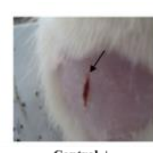

Control +

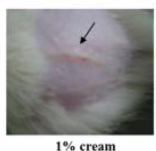

$1 \%$ cream

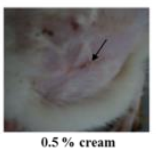

$0.5 \%$ cream

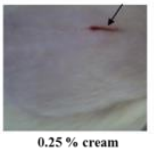


Creams are semisolid dosage forms intended mainly for external use and commonly consist of two immiscible phases, an oily internal phase and an aqueous external phase. Due to emulsified nature of skin surface, drugs formulated as cream more effectively interact with skin and more readily penetrate through biological membranes. Some of plant extracts with antifungal activity have been previously formulated as topical creams (32). This reduction of size of wound and crust loss in days, shows evident differences in favor of antibacterial plant compound (a). Not only changes in size wound but also significant contraction in the first day after cream treatment in comparison with $72 \mathrm{~h}$ of untreated wounds. Furthermore, the count of bacteria from infected mice may be inconsistent (33) and for that reason, other methods can be recommended in addition as bioluminescent monitoring (34) or the culture of supernatant of skin (35). Overall, the skin cream showed good antimicrobial

Efficacy. In all extract treatment groups did not show any infection while negative control, there was some infection without pus between recurrences. The absence of infection is the absence of specific and limited damage to the wound tissue due to microbial invasion; which is characterized by the absence of signs of inflammation calor, rubor, tumor, dolor, function laes. Likewise for the level of allergy, which does not show any red spots in the area around the wound (36). The antibacterial test results showed that Coleus leaves cream had the potential to inhibit the growth of Sa. Comparison of antibacterial test results at the three concentrations showed that $1 \%$ concentration had more effective antibacterial power with faster wound healing time than $0.5 \%$ and $0.25 \%$ concentrations. Concentrations of $0.5 \%$ and $0.25 \%$ were less effective in providing wound healing because the active compound given was too small so that the release of the active substance on the cream base was little.

Then the positive control had a slower wound healing time than the myana leaf cream group (Figure 3). This seems due to in low concentrations, tetracycline has a less effective role in the wound healing process and as an antimicrobial. The results of the macroscopic wound test after administration of extract cream with concentrations of $1 \%, 0.5 \%$, and $0.25 \%$ against Sa with five repetitions are presented in Table 6 . Wound healing time was observed by looking at the time for tissue repair; characterized by a clean surface, little granulation, and no tissue loss. The data showed that there were differences in the recovery time at the three concentrations. The results of the calculation of the average healing time showed that a concentration of $1 \%$ could heal an average of 7 days, an average concentration of $0.5 \%$ was 14 days, and a concentration of $0.25 \%$ an average of 14 days. The concentration of $0.5 \%$ has a cure time with a mean that is not significantly different from a concentration of $0.25 \%(15,37,38)$.

Previous research reported that the extract of Zataria multiflora formulated as a topical cream may lead to enhancement of stability and acceptability of the bioactive ingredient (39). In another report, anti-dermatophytic cream from methanol extract of Eucalyptus camadulensis, base formula contained excess fat which produced a greasy sense on usage, turbidity and its low consistency (40). Therefore, the formula was modified to overcome the problems. The best formulation was chosen according to the results of different chemical and physical tests. Control experiments and stability determination showed a stable homogeneous appearance during the storage period and no separation phase occurred.

\section{Conclusions}

Our finding that, Coleus leaves ethyl acetate extract contains alkaloids and tannins, the absorbance of Sa at the 3rd hour was getting smaller, from 0.668 to 0.552 , this showed that the longer the incubation time of the extract against bacterial inoculation, the more bacteria died. Our cream formulation with criteria: the $\mathrm{pH}$ value, homogeneity, spreadability, adhesion, and protection power. Our cream formulation results were then evaluated based on the standard, with criteria: the $\mathrm{pH}$ value, homogeneity, spreadability, adhesion, and protection power. It seems that our cream is per the cream standards. It is semi-solid, brownish-white in color, smells typical of Coleus, and $\mathrm{pH}$ 6. Moreover, the cream is homogeneous with $5 \mathrm{~cm}$ of spreadability, 7 seconds for adhesion, and colorless. Moreover, we found that Coleus extract cream has better antibacterial activity than positive control with a wound closure time of 7-14 days for extract while more than 14 days for positive control

\section{Acknowledegements}

Thanks to Research and Technology, Higher Education and LPPM University of Jambi for the Grant for Beginner Lecturer Research Scheme (PDP).

\section{Conflict of Interest}

None 


\section{References}

1. Fiana FM, Kiromah NZ, Purwanti E. Aktivitas Antibakteri Ekstrak Etanol Daun Sukun (Artocarpus altilis) Terhadap Bakteri Staphylococcus aureus Dan Escherichia coli. Pharmacon: Jurnal Farmasi Indonesia. 2020 Jul 7:10-20.

2. Anisa A, Ambarwati M, Triani AA, Tarigan IL. Modification of Nanocellulose as Conjugate of infectioncausing Antibacterial Hydrogel. Fullerene Journal of Chemistry. 2021 Apr 30;6(1):58-70.

3. Signore A. About inflammation and infection. EJNMMI research. 2013 Dec;3(1):1-2.

4. Alkandahri MY, Subarnas A, Berbudi A. Aktivitas Immunomodulator Tanaman Sambiloto (Andrographis paniculata Nees). Farmaka. 2018 Oct 31;16(3):16-21.

5. Prihannensia M, Winarsih S, Achmad A. Uji Aktivitas Sediaan Gel Dan Ekstrak Lengkuas (Alpinia galanga) Terhadap Bakteri Staphylococcus Epidermidis Secara In Vitro. Pharmaceutical Journal of Indonesia. 2019 Jan 24;4(1):23-8.

6. Paju N, Yamlean PV, Kojong N. Uji efektivitas salep ekstrak daun binahong (Anredera cordifolia (Ten.) Steenis) pada kelinci (Oryctolagus cuniculus) yang terinfeksi bakteri Staphylococcus aureus. Pharmacon. 2013 Feb 1;2(1).

7. Mahizan NA, Yang SK, Moo CL, Song AAL, Chong CM, Chong $\mathrm{CW}$, et al. Terpene derivatives as a potential agent against antimicrobial resistance (AMR) pathogens. Molecules. 2019;24(14):1-21.

8. Erikawati D, Santosaningsih D, Santoso S. Tingginya Prevalensi MRSA pada Isolat Klinik Periode 2010-2014 di RSUD Dr. Saiful Anwar Malang, Indonesia. Jurnal Kedokteran Brawijaya. 2016 Aug 29;29(2):149-56.

9. Odonkor ST, Addo KK. Bacteria resistance to antibiotics: recent trends and challenges. International Journal of Bioligcal and Medical Research. 2011 Oct;2(4):1204-0.

10. Malmsten M. Handbook of Nanomaterials Properties. Eds:B. Bhu. Springer. Berlin.; 2014. 108-120 p.

11. 11. Bahi M. Senyawa Antibiotika dari Bakteri dan Jamur Endofit: Mini review. Prosiding SEMIRATA 2013. 2013 Oct $1 ; 1(1)$.

12. Cisilya T, Lestario LN, Cahyanti MN. Kinetika Degradasi Serbuk Antosianin Daun Miana (Coleous scutellarioides L. Benth) Var. Crispa Hasil Mikroenkapsulasi. Chimica et Natura Acta. 2017 Dec 15;5(3):146-52.

13. Suva MA, Patel AM, Sharma N. Coleus species: Solenostemon scutellarioides. Inventi Rapid: Planta Activa. 2015;2015(2).

14. Tari R, Posangi J, Wowor P. TERHADAP PENYEMBUHAN LUKA INSISI PADA KULIT KELINCI ( Oryctolagus cuniculus ). e-Biomedik (eBM). 2013;1((1)):5816.

15. Parmadi A, Rejeki S. Efektivitas dan Uji Evaluasi Sedian Krim Ekstrak Etanol Daun Mengkudu (Morinda citrifolia L) Sebagai Obat Penyembuh Luka. IJMS-Indonesian Journal on Medical Science [Internet]. 2019;6(1):38-44. Available from: http://ejournal.ijmsbm.org/index.php/ijms/article/view/165

16. Kamoun EA, Kenawy ER, Chen X. A review on polymeric hydrogel membranes for wound dressing applications: PVA-based hydrogel dressings. Journal of advanced research. 2017 May 1;8(3):217-33.

17. Chalke T, Sharma K, Nagare S, Jirge S. Formualtion and Evaluation of Punica Topical Gel for its Content of Gallic Acid and Anti-Microbial Study. International Journal of Drug Delivery Technology. 2016;6(03):75-8.

18. Ashadi RW. SINTESIS Biodegradable Hydrogel dari Amorpophallus Oncophyllus. Jurnal Pertanian. 2017 Mar 22;1(1):9-16.

19. Tarigan IL, Sari AK, Huda C, Jovanncha C, Muadifah A. Phytochemical Screening and Quantitative Analysis of Coleus arthropurpureus Ethyl Acetate Fraction and Antibacterial Activity Against Staphylococcus aureus. ALKIMIA: Jurnal Ilmu Kimia dan Terapan. 2020 Feb 29;4(1):17-23.

20. Gusti DR, Maulana RG, Permana E, Lestari I, Tarigan IL. Profile Analysis of Fatty Acids of Tengkawang (Shorea Sumatrana) Oil Using GC-MS and Antibacterial Activity. Indonesian Journal of Chemical Research. 2020 Sep 30;8(2):114-9.

21. Kimia J, Tadulako U, Bumi K, Tondo T. Antibacterial Activity of Mayana Plant Leaf Extract (Coleus atropurpureus [L] Benth) Using Several Levels of Solvent Polarity. KOVALEN Jurnal Riset Kimia. 2018;4(2):180-9.

22. Edy HJ, Wahyuono S, Endro A, Farmasi S, Mipa F, Ratulangi US, et al. Pengujian Aktivitas Antibakteri Hidrogel Ekstrak Etanol Daun Tagetes erecta L .). Jurnal MIPA. 2019;8(3):96-8.

23. Tarigan IL, Muadifah A, Amini HW, Astutik TK. Studi aktivitas ekstrak etanol dan sediaan gel daun melinjo (Gnetum gnemon L) sebagai antibakteri terhadap Staphylococcus Aureus. Chempublish Journal. 2019 Dec 31;4(2):89-100.

24. Dewantari DR, Sugihartini N. Formulasi dan Uji Aktivitas Gel Ekstrak Daun Petai Cina (Leucaena glauca, Benth) Sebagai Sediaan Obat Luka Bakar. Farmasains. 2015;2(5):217-22.

25. Wibowo SA, Budiman A, Hartanti D. Formulasi Dan Aktivitas Anti Jamur Sediaan Krim M/A Ekstrak Etanol Buah Takokak (Solanum torvum Swartz) Terhadap Candida albicans. Riset Sains dan Teknologi. 2017;1(1):22-36.

26. Pérez M, Robres P, Moreno B, Bolea R, Verde MT, PérezLaguna V, Aspiroz C, Gilaberte Y, Rezusta A. Comparison of antibacterial activity and wound healing in a superficial abrasion mouse model of Staphylococcus aureus skin infection using photodynamic therapy based on methylene blue or mupirocin or both. Frontiers in Medicine. 2021;8.

27. Mai-Prochnow A, Clauson M, Hong J, Murphy AB. Gram positive and Gram negative bacteria differ in their sensitivity to cold plasma. Scientific reports. 2016 Dec 9;6(1):1-1.

28. Saga T, Yamaguchi K. History of antimicrobial agents and resistant bacteria. Japan Medical Association Journal. 2009;52(2):103-8.

29. Anita A, Basarang M, Rahmawati R. Uji Daya Hambat Ekstrak Daun Miana (Coleus atropurpureus) terhadap Escherichia coli. Jurnal Media Analis Kesehatan. 2019 Jul 24;10(1):72-8.

30. Haris A. Efektivitas Krim Ekstrak Sarang Burung Walet Terhadap Penyembuhan Luka Mencit Di Kota Bima. Jurnal Analis Medika Biosains (JAMBS). 2019 Sep 3;6(2):120-4. 
31. Cushnie TT, Cushnie B, Lamb AJ. Alkaloids: An overview of their antibacterial, antibiotic-enhancing and antivirulence activities. International journal of antimicrobial agents. 2014 Nov 1;44(5):377-86.

32. Handali S, Hosseini H, Ameri A, Moghimipour E. Formulation and evaluation of an antibacterial cream from Oxalis corniculata aqueous extract. Jundishapur Journal of Microbiology. 2011;4(4):255-60.

33. Ogunniyi AD, Kopecki Z, Hickey EE, Khazandi M, Peel $\mathrm{E}$, Belov K, et al. Bioluminescent murine models of bacterial sepsis and scald wound infections for antimicrobial efficacy testing. PLoS One. 2018;13(7):1-13.

34. Guo Y, Ramos RI, Cho JS, Donegan NP, Cheung AL, Miller LS. In vivo bioluminescence imaging to evaluate systemic and topical antibiotics against community-acquired methicillin-resistant Staphylococcus aureus-infected skin wounds in mice. Antimicrobial agents and chemotherapy. $2013 \mathrm{Feb} ; 57(2): 855-63$.

35. Abrha S, Bartholomaeus A, Tesfaye W, Thomas J. Impetigo animal models: A review of their feasibility and clinical utility for therapeutic appraisal of investigational drug candidates. Antibiotics. 2020;9(10):1-18.

36. Sánchez-Quesada C, López-Biedma A, Toledo E, Gaforio JJ. Squalene stimulates a key innate immune cell to foster wound healing and tissue repair. Evidence-Based Complementary and Alternative Medicine. 2018 Jan 1;2018.

37. Husni P, Amalia AD, Mita SR, Putriana NA, Januarti M. Formulation and Physical Evaluation of Cream Containing Neem Oil 5\%. IDJP (Indonesian Journal of Pharmaceutics). 2019 Oct 1;1(3):72-6.

38. Safitri FW, Syahreza A, Sulistyaningrum IH. Antioxidant activities and antioxidant cream formulation of corn silk (Zea Mays L) extract. Sains Medika: Jurnal Kedokteran Dan Kesehatan. 2016;7(2):64-9.

39. Aghela Nasrin, Eskandar Moghimipourb AA. Characterization of an Anti-Dermatophyte Cream from Zataria multiflora Boiss. Iran Journal of Pharmaceutical Science Spring. 2007;7(3):151-8.

40. E. Moghimipour, A. Ameri, A. Saudatzadeh, A. Salimi AS. Formulation of an Anti-Dermatophyte Cream From Hydro-Alcoholic Extract of Eucalyptus. Jundishapur Journal of Natural Pharmaceutical Products. 2009;4(1):32-40. 